\title{
Creation of an Experimental Platform for Preschool Children as Part of Project Training of Students of Pedagogical Specialties at North-Eastern State University (Russian Federation)
}

\author{
Lada Yu. KALININA \\ $\mathrm{PhD}$ (Mining and Geology), Associate Professor \\ Head of the Department of Geology and Earth Physics, Polytechnic Institute \\ North-Eastern State University \\ 13 Portovaya st., Magadan, 685000, Russian Federation \\ Phone: 7(4132)616894 \\ E-mail: lada_kalinina@mail.ru \\ Tatiana V. SUBBOTNIKOVA \\ Senior Lecturer of the Department of Geology and Earth Physics, Polytechnic Institute \\ North-Eastern State University \\ 13 Portovaya st., Magadan, 685000, Russian Federation \\ Phone: 7(4132)616894 \\ E-mail: tatsub@mail.ru
}

\begin{abstract}
The purpose of the article is to summarize and analyze the experience of using project-based learning technology at the Institute of digital technologies and Economics of North-Eastern state University. Methodology and methods. In the course of the work, based on a practice-oriented approach, empirical research methods were used. As a result of the project implementation "Simple science", experimental cognitive classes for preschoolers were developed and tested to introduce children to the laws of nature in an accessible form and to develop an interest in learning the world. Working on the project helped to increase the motivation for training, develop self-education skills, the ability to solve specific practical tasks, to become a leader and be able to interact within the team. The practical significance of the work is the possibility of using its methods and results in the design of educational activities in the system of teacher education.
\end{abstract}

Keywords: practice-oriented approach; new learning technologies; project method; children's experimentation; cognitive interest.

\section{Introduction}

Currently, the task of higher education institutions is to train specialists not only with a set of professional knowledge, skills, but also with energy, communication skills, the ability to build a career trajectory, set goals and solve problems, and be able to work in a team.

To do this, it is necessary to use new teaching methods in the educational process that help students gain experience in solving various tasks independently, applying theoretical knowledge in practice. One of these methods is the project-based method, which is currently widely discussed in the scientific literature, both in terms of theoretical and methodological aspects, and practical application (Emelyanova et al., 2012, Pak et al., 2016, Poddyakov, 1977, Trischenko, 2018, Ginestié, 2002, Mo et al., 2017, Palmer et al., 2011, Queiroz-Neto et al., 2015, Vahtikari et al., 2012).

The project methodology is a person-oriented educational technology (Polat, 2010), which is a key factor in choosing this method in the process of higher education. The article of Sharipov (2012, p. 90) gives the following definition of an educational project: "it is a product independently developed and manufactured by students (material or intellectual) from the idea to its 
implementation, having a subjective or objective novelty, performed under the supervision and consultation of the teacher". Zainullina (2016) considers the technology of project-based learning to be one of the most effective, motivating students to independently acquire skills and abilities in the process of combining knowledge of different subjects, solving specific practical problems. During the preparation and implementation of projects, students acquire and improve the ability to apply their knowledge in practice, navigate non-standard situations, analyze emerging problems, and work in a group (Gladkova et al., 2018, Kalinina, 2018, Solovyov et al., 2009).

The Institute of digital technologies and Economics of North-Eastern state University together with the Children's development center "Academiya pochemuchek" implemented the project "Simple science". The project is aimed at increasing the interest of students of pedagogical specialties in their future profession, developing the ability to search, critical analysis and synthesis of information through the development of experimental scientific and educational classes for preschoolers.

\section{Methods}

Children experimentation is a method of learning aimed at obtaining new knowledge that allows the child to be active. In modern pedagogical practice, when working with preschoolers, more and more emphasis is placed on creating conditions for independent search and creative activity of children. Podyakov (1977) considers children experimentation as the main form of research activity of children in preschool age.

The use of search and research activities in the pedagogical process develops the intellectual abilities of preschool children, their independence, the ability to put forward hypotheses and assumptions, and mere the experiment. The Chinese thinker Confucius said: "Tell me and I'll forget, show me and I'll remember, let me do it and I'll learn." The more actively a child touches, sniffs, listens, experiments, explores, and discusses, the faster their intellectual abilities develop, and their cognitive activity increases (Goncharova, 2018). All these qualities contribute to the further successful learning of the child in school.

\section{Results}

The goal of the "Simple science" project is to organize experimental research activities with preschoolers to develop thinking, imagination, speech, and interest in learning about the world around them. During the implementation of the project, student teams were to develop and test experimental educational classes for preschoolers, introduce them to the basic laws of nature for children, and show that science is not boring, but extremely interesting! Approbation of the project took place at the classes of the club "Shkola experimentov" (School of experiments) on the basis of "Academia pochemuchek", Magadan.

To achieve this goal students solved the following tasks:

- To develop activity, curiosity and cognitive interest in children in the process of organizing elementary experiments, observations and research.

- To teach children to put forward hypotheses, to observe, to analyze and draw simple conclusions.

- To expand the understanding of natural phenomena and various properties of objects in the world around them.

- To learn to record the results of observations.

- To shape the experience of implementation of safety rules when carrying out experiments.

In the course of preparation, thematic planning was developed and a number of experiments were selected for it. Experiments should be easy to perform and safe for children. Table 1 shows an approximate thematic lesson plan and some of the experiments used in the class. 


\section{Table 1. Thematic planning}

\begin{tabular}{cl}
\hline Topic & Content \\
\hline "Big lab for the little ones" & $\begin{array}{l}\text { Scientists are people who study the world around them. Introduce you to the } \\
\text { safety procedures in the laboratory and the rules for conducting the } \\
\text { experiment. }\end{array}$
\end{tabular}

"Unusual boats"

"Magic water"

"Air"

"Sound"

"Magic light"

"The sun gives us warmth and light"

"3 States of matter"

"The most amazing substance on earth" "Glass". "Mirror"

"Soap-the magician"
Bring to the understanding of the concepts: light - heavy, floats-sinks.

Materials: a container with water, objects of different shapes made of different materials (plastic, wood, stones, screw nuts).

Description: Children examine all objects and compare them with each other. The host asks the children to help him find out: can all these items float? Offers them to check for themselves what items will float. Children lower the objects into the water and watch. Do all objects float? Do they all have the same size? Why do they float? The host helps children to compare the floatage of balls made of different materials and sizes.

To introduce the main properties of water (no taste, shape, smell and color), fluidity and transparency of water.

Materials: a container with cold and warm water, paints, colored stones, a stick for stirring.

Description: The host examines objects in the water together with the children. Why are they clearly visible? Water can be made colored if you add paint (some items dissolve in water). The color of the water will become the same as the color of the paint. Paints dissolve faster in warm water.

To introduce the basic properties of air: invisible, no shape, can move. To introduce the concept of atmospheric pressure.

Materials: glass, straw, cardboard, water container.

Description: Can I see the air? You need to put a straw in the water and blow. Bubbles appear. Air is lighter than water, it rises up. The host covers the glass with cardboard and turns it over. The cardboard does not allow water to pour out. Why does it keep water? The air helps the cardboard (atmospheric pressure).

To introduce the basic properties of sound: the speed of sound, the strength of sound, the source of sound, ringing-dull.

Materials: a long ruler, a "simple phone": two small paper cups, their bottoms are pierced in the center and a thin cord several meters long is threaded through them, fixed to the bottom of the glasses.

Description: Does the ruler have a voice? If you don't touch the ruler, it doesn't make a sound. The host presses one end of the ruler tightly against the table, hitting the free end. The ruler makes a sound. Why did the sound appear? Because the ruler is shaking.

"Simple phone" - participants in the conversation get a "phone" and go to different ends of the room. One child speaks into a glass, the other hears it (even if speaking softly). Why is the sound clearly audible? Where does sound travel faster, in the air or in the cord?

To introduce the properties of light. Understand the values: transparent, nontransparent, semi-transparent, shadow formation, light brightness.

To give children the idea that the Sun is a source of heat and light. To introduce the concept of "light energy". To show the degree of its absorption by different objects and materials.

To find out that a substance can be in three aggregate states: gas, liquid, and solid.

To establish the dependence of changes in nature on the season. Snow-water. To highlight the main properties of snow and ice.

To introduce the main properties and qualities of glass. Type of glass. Magnifying glass. To identify features of the reflection mirrors.

To introduce the properties and purpose of soap; to develop observation, curiosity. We make soap bubbles. 


\begin{tabular}{ll}
\hline "Magnet" & To introduce the magnet and its properties. \\
Materials: magnet, light items (iron and plastic, wooden), semolina. \\
Description: Light iron objects covered with semolina. How do we get the \\
treasure? We need to get a magnet. Experience shows that you can only get \\
iron objects. You can use items made of different metals (copper, silver, \\
iron).
\end{tabular}

\section{Discussion}

Working on the project "Simple science" allowed students to draw the following conclusions:

1. Children try to organize and explain the world around them in their imagination. With the help of a teacher, a child develops scientific thinking, gets acquainted with natural phenomena, with the sciences that study these phenomena, learns to conduct experiments and draw conclusions.

2. The child develops his character. After all, in order to conduct even the simplest experience, he must show patience and perseverance.

3. Positive experience from the work done generates a deep interest in science, shows that diligence leads to achievements.

Students noticed that children's curiosity does not end in the classroom. When they came home, preschoolers tried to implement their knowledge. They not only repeated the experiments that surprised them, but also came up with new variations, trying their hand at their own research.

\section{Conclusion}

Children and parents highly appreciated the efforts of novice teachers. There was a high activity of children and their interest. The results of the project showed its effectiveness.

It allowed us to achieve the following educational results.

For preschoolers:

- Expansion of ideas about the world around us, about the sciences that study the laws of nature.

- Positive dynamics in mastering explanatory and evidence-based speech.

- Formation of the simplest skills of working with equipment for children experimentation.

- Development of responsibility, independence, self-confidence, goodwill, ability to work in a team.

For students:

- Development of the ability to search, critical analysis and synthesis of information, the use of a systematic approach to solve tasks.

- Gaining experience in project development and implementation - the ability to choose the best ways to solve problems based on available resources and limitations.

- Improving skills to work in a team, to be a leader.

- Self-organization and self-development - managing your own time, implementing the trajectory of self-development.

- Development of information culture - the use of information and communication technologies.

The implementation of the project method in the educational process allowed the project participants to learn more about their future profession, helped to increase the motivation of training, actively develop the content of training, which ultimately allows to significantly improve the level and quality of professional training in general. 


\section{References}

Emelyanova, N.V., Larionova, O.G. (2012). Organizatsiya proyektnogo obucheniya v vuze [Organization of project-based learning at a higher educational institution]. Issues of Social Economic Development of Siberia, 1(8), 70-75.

Ginestié, J. (2002). The Industrial Project Method in French Industry and in French Schools. International Journal of Technology and Design Education, 12(2), 99-122. DOI: 10.1023/A:1015213511549

Gladkova, M.N., Vaganova, O.I., Kutepov, M.M. (2018). Primeneniye proyektnykh obrazovatel'nykh tekhnologiy v uchebnom protsesse vuza [Application of design educational technologies in the training process of the higher educational institution]. Baltic Humanitarian Journal, 7, 2(23), 209-212.

Goncharova, N.G. (2018). Detskoye eksperimentirovaniye v period razvitiya rebenka [Childrens experimentation during the gestation period]. Voprosy Doshkolnoy Pedagogiki, 5(15), 1316. https://moluch.ru/th/1/archive/100/3500/

Kalinina, L.Yu. (2018). Primeneniye metoda proyektov pri podgotovke inzhenerov $v$ Politekhnicheskom institute Severo-Vostochnogo gosudarstvennogo universiteta. Razvitiye sovremennogo obrazovaniya: ot teorii $k$ praktike [Application of the project method in the training of engineers at the Polytechnic Institute of North-Eastern state University. Development of modern education: from theory to practice]. Proceedings of the $V$ International Scientific-Practical Conference. (Cheboksary, July 25, 2018, pp. 9-11). Cheboksary: Interaktiv plus.

Mo, J. P. T., Tang, Y. M. (2017). Project-based learning of systems engineering V model with the support of 3D printing. Australasian Journal of Engineering Education, 22(1), 3-13. DOI: $10.1080 / 22054952.2017 .1338229$

Pak, V.V., Melnikova, T.N., Sotiriadi, G.N. (2016). Ispolzovaniye uchebnykh zadach po fizike $s$ tselyu formirovaniya obobshchennykh proyektnykh umeniy [The use of learning tasks in physics with the aim to form common project abilities]. Modern science based technology, $6,174-178$.

Palmer, S., Hall, W. (2011). An evaluation of a project-based learning initiative in engineering education. European Journal of Engineering Education, 36(4), 357-365. DOI: $10.1080 / 03043797.2011 .593095$

Poddyakov, N. N. (1977). Myshlenie doshkolnika [Thinking of a preschool child]. Moscow: Pedagogy.

Polat, E. S. (2010). Sovremennye pedagogicheskie $i$ informatsionnie tekhnologii $v$ sisteme obrazovaniya [Modern pedagogical and information technologies in the education system]. Moscow: Academy.

Queiroz-Neto, J. P., Sales, D.C., Pinheiro, H. S., Neto, B. O. (2015). Using modern pedagogical tools to improve learning in technological contents. IEEE Frontiers in Education Conference (FIE), El Paso, pp. 1-8. DOI: 10.1109/FIE.2015.7344383

Sharipov, F.V. (2012). Tekhnologiya projektonogo obychenia [Project-based learning technology]. Pedagogical Journal. Bashkortostan, 2(39), 87-93. 
Solovyov, A. N., Stepanyan, I. K. (2009). Metod proektov v pedagogike vyshei shkoly: istoria $i$ perspektivy [Method of projects in higher school pedagogy: history of development and prospects]. Bulletin. MGUKI, 4(30), 143-148.

Trischenko, D.A. (2018). Opyt proektonogo obychenia: popytka objektivnogo analyza dostizhenii $i$ problem [Experience of project training: an attempt to objectively analyze achievements and problems]. Education and science, 20(4), 132-152.

Vahtikari, K., Silvo, J., Kairi, M. (2012). Project-based learning for Master students - case Integrated Interior Wooden Surfaces. In P. Quenneville (Ed.), 12th World Conference on Timber Engineering. Auckland, New Zealand. July 15-19, 2012, pp. 315-322. https://research.aalto.fi/en/publications/project-based-learning-for-master-students-caseintegrated-interi

Zaynulina, F.K. (2016). Proyektnyy metod obucheniya v formirovanii motivatsii obrazovatel'nogo protsessa studentov [The design method of teaching when forming the motivation of the educational process of students]. Bulletin. Kazan state University of Culture and Arts, 4, 164-167. 